\title{
MCDM for Selecting the Best ICT Enabled Wireless Control for the Process Industry- A Case Study
}

\author{
Jayalakshmi.B, \\ Research Scholar, Mechanical Engineering \\ Department, Karpagam University, Coimbatore, Tamil \\ Nadu, India \\ (Associate Professor, I C E Dept, \\ NSS College of Engineering, \\ Palakkad, Kerala, India)
}

\author{
Pramod.V.R \\ Associate Professor, Mechanical Department, \\ NSS College of Engineering, \\ Palakkad, \\ Kerala, India
}

\begin{abstract}
Implementation of Information and Communication Technology (ICT) enabled wireless control systems to manage plant operations are growing far and wide. Several ICT enabled wireless remote open loop systems such as wireless transmitters, control valves and smart sensors are available now. However, such systems are not yet introduced in the control of processes. In this work, authors attempt to choose the best suitable ICT enabled wireless control method in process industries, with the help of industrialists in a leading fertilizers and chemicals industry in central Kerala. For decision-making Analytic network process (ANP), a powerful tool in multi-criteria decision-making is used and it analyzes the performances of the control methods. Three types of control models are introduced for the ANP analysis. Control within the process, centralized control within a particular area and control from geographically diverse locations are the wireless control models used for the analysis. ANP measures the comparative strength and impact between elements in the network models. This decision model incorporates and relies upon the distinctiveness of ICT enabled control system. The result indicates that the best suitable control method is control within the process.
\end{abstract}

\section{Keywords}

ANP; Multi Criteria Decision Making (MCDM);ICT; Wireless control system; Super matrix; Total desirability indices

\section{INTRODUCTION}

Information control technology is a strategy that has been subject to wide implementation of remote control methods for the process industry; but till now only very little research work has been done to develop systematic design methods or for the design of ICT based process control systems, using this technology. The initial costs to implement the ICT enabled wireless systems are high too. Therefore, it is very important to make the entrepreneurs and their staff aware of the paybacks of ICT in order to implement it successfully.

Recent industrial processes are working with wired systems such as distributed control system and a supervisory control and data acquisition system to control it. This requires large quantity of connecting cables depending upon the distance between the control room and the plant. Being a wireless control system, ICT enabled process control system consumes only a lesser space and not worried about distance between control room and process. Other advantages of offering ICT enabled wireless process control system are cheap installation cost, better control, and reliability. When compared to Internet based process control systems, hacking can be reduced to a prominent extent by introducing a highly secure system. Controlling an industrial process from geographically diverse locations is a great achievement in industrial development using ICT. Industries are now familiar with ICT enabled wireless transmitters and control valves; the open loop systems. In laboratories of some distant education programs, where much accuracy and real time operation are not required, they use ICT enabled remote monitoring [1]. Closed loop remote monitoring systems are still not introduced in the industry where high accuracy and better real time operations are needed. This lack of ICT enabled remote control in the industries inspired the authors to propose the present work. Authors conducted a survey among five process industries. The survey results also indicated that no effort to introduce wireless remote control of process had been reported in practice.

In this work, authors make an attempt to analyze the best ICT enabled wireless process control system for the industries. Analytical Network Process (ANP) carried out analysis. ANP is a quantifiable methodology to deal with inter-reliant relationships within a multi-criteria decision-making framework. This tool is used to recapitulate the interdependences in different levels of decision attribute. In ANP, the decision problem is organized in a hierarchical manner with network having clusters and connecting nodes. The network essentially consists of four clusters; first cluster consists of dimensions and have four elements. Next is a cluster of determinants, which also have four elements. Each of these determinants has its own enablers. There is no interrelationship between these groups of enablers. Pair wise comparisons and judgment are made to make a decision. All those factors, which influence the process, will affect the optimality of the choice $[2,3]$. ANP is one of the multi-criteria decision making technique [3]. In ANP the intangible aspects are taken into consideration by taking pair-wise comparison [4]. ANP can be selected due to its aptness in contributing solutions in a composite multi-criteria decision situation [5]. ANP, being a powerful tool in multi-criteria decision making, can be used for selecting the best cloud computing among Public cloud, private cloud and hybrid cloud [6]. ANP is also used, to analyze and allocate the right mix of training solutions in the U.S. army training support system [7], to promote the quality of the physical therapies in children [8]. The Web service selection is a multifaceted decision process, in which, the selection of candidate service from a set of available services is effectively done by using ANP [9]. Being a multi attribute tactical decision making process, ANP is used to select the apt software for the development of a particular 
product [10]. It is also effectively used to select the best location for a waste incinerator plant in the Province of Torino in Italy [11].

The decision problem is organized in a hierarchical manner and the enablers, determinants and dimensions are allied with the alternatives. In this work, authors attempt to choose the best suitable ICT enabled wireless control method in process industries with the help of industrialists from a fertilizers' and chemicals' industry-ABC-in central Kerala. ABC was established in 1965 and has four divisions in central Kerala. As a prerequisite for implementing the proposed model in $\mathrm{ABC}$, an ANP based model case study was carried out by a group of experts in ABC. This along with the literature survey had derived the determinants, dimensions and enablers. The proposed ANP framework is implemented and evaluated. According to the experts, desirable characteristics of ICT enabled process control systems are process optimization, intelligent and information management system, smart metering technology and robust and reliable technology. Selection of the best process control system also depends on pioneering method, information security, real time operation and wireless control. Alternatives in this work are control within the process, centralized control within a particular area and control from geographically diverse locations.

The ratio scale priority vectors which are derived from pairwise comparison matrices are not synthesized linearly in the ANP. Ratio scales are synthesized by exploring an improved super matrix technique. Each ratio scale is brought to a column in a matrix representing the impact of elements in a cluster on an element in another cluster or one element in another cluster. Several sub- matrix are together to compose the super matrix; each of its column is Principal Eigen vector. This principal Eigen vector represents the impact of all elements in a cluster on each of the elements in another cluster. Not every elements of a cluster need require having an influence on an element in another cluster. In such cases, the elements are given a zero value for their contribution. The super matrix that is composed of ratio scale priority vectors derived from pair -wise comparison matrices and the zero vectors, must be apt to obtain meaningful limiting results. Super matrix for each dimension is evaluated; and then the same super matrices can be converged using MATLAB. ANP has further evaluated the total desirability indices.

The proposed model successfully models the ambiguity and imprecision in the pair wise comparison process. It also helps to reduce the personal biasness. The presented model provides numerous qualitative and qualitative factors; and thus offers the importance level of each criteria/sub-criteria. This will help the decision maker to understand the factors, which should be given importance.

\section{RESEARCH METHODOLOGY}

ANP hierarchy for the selection of ICT enabled process control system is shown in figure1. In ANP, Pair wise comparative judgment is done based on the influence of the considered elements. The determinant represents the aspects to achieve objective of the problem. Determinants act as motivators. Determinants of ICT enabled process control systems are considered as process optimization, intelligent automation and information management system, smart metering technology, robust and reliable technology. Dimensions are the fields in which the objectives have aftereffects. Here the dimensions considered are pioneering method, information security, real time operation, and wireless control. Alternatives considered are control within the process, Centralized Control within a
Particular Area and Control from Geographically Diverse Locations.

The objective is to adopt the best ICT enabled process control model. The determinants are displayed followed by dimensions. Enablers support in attaining dimensions and have interdependences. This is shown as arrow arching back to the enablers' decision level.

\section{IMPLEMENTATION PROCEDURES}

\subsection{Theory section}

Wireless transmission is used and has become a part of everyone's life. Products with wireless capabilities are being developed and updated every day. The benefits of flexibility and mobility make the use of wireless equipment almost a necessity. The use of wireless networks in industrial automation has increased in the past few years due to the advantages such as the reduction of time, cost to install new devices, since there is no need to provide a cabling infrastructure and ease of use. According to the experts in $\mathrm{ABC}$, while adopting ICT enabled wireless control system technology, many important requirements also should be considered. The most important requirements being a pioneering method are: reliability, security, robustness, smart metering technology, real time operation, intelligent automation and process information management etc.

The security mechanisms must be evaluated using the following criteria: confidentiality of information, integrity of information and availability of information. The confidentiality of information guarantees that only the authorized network members will have access to the information. Security software is available in market, in which information can be protected through the use of encryption, along with hop-to-hop security and end-to-end security [12].The integrity of the information is ensured through proper mechanisms. The availability of the information can be broken by continuous or intermittent interference in the communication channels. When there is continuous interference in several channels, the channel blacklisting will provide an efficient solution. In case of intermittent interference, the channel hopping is an appropriate solution [13]. In addition, the transmission spectrum is continuously monitored to avoid all these types of problems. Essential requirements of real time operation of the system are to reduce the operation time delay and instantaneous control action. Even though the cost of implementing an ICT enabled control system is high, increase in production make it cost effective.

For providing robust on-site communications, a meshing system is operated by the wireless option. The system ensures that all nodes have the facility of at least two routes back to the master station. So even when the normal traffic route is blocked, the network will find an alternate way to route the messages. In addition to the said security measures, the security of data over the air can be ensured by using encryption facilities [14].

Efficiency is a very important factor for a process control system. With high efficiency, production can be increased. When considering the implementation of an innovative method, ease of use must be considered. That means system must be user friendly. For the optimization of the plant operation, the proposed system must be cost effective. Flexibility and mobility must be strongly considered for the proposed system. 


\subsection{Calculation section}

A nine step approach is used for the model case study as revealed herewith.

\subsubsection{Step1:-Model development and Problem formulations}

The decision problem adoption of best ICT enabled process control system deployment model is structured with the four determinants process optimization, intelligent automation and information management system, smart metering technology, robust and reliable technology. Four dimensions follow it. The enablers for pioneering method are immense future scope, enhancement of production, much opportunity for research and high initial investment. The enablers for information security are information integrity, information confidentiality, and information protection. The enablers for real time operation are instantaneous control action, minutest operation delay and simultaneous control of different physical variables. The enablers for wireless operation are greater flexibility and mobility for users, better efficiency, cheap installation \& maintenance cost, and user friendly. Alternatives are control within the process, centralized control within a particular area and control from geographically diverse locations. ANP model for the adoption of best ICT enabled process control system is shown in figure 1.

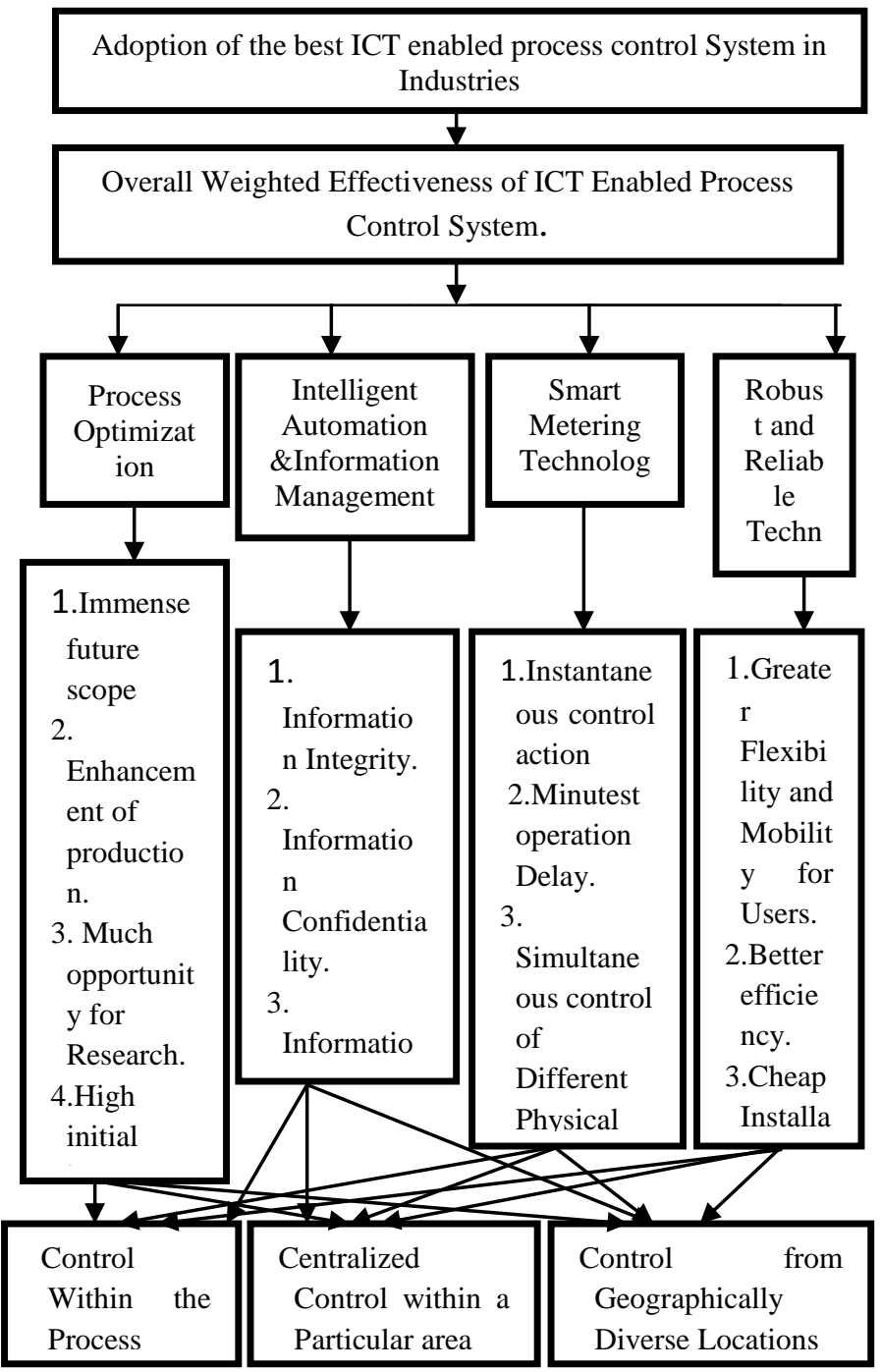

Fig .1 ANP Model for ICT enabled process control system

\subsubsection{Step 2:- Pair-wise comparison of the} determinants:

A group of experts from $\mathrm{ABC}$ was chosen to give their valuable suggestions. The familiarity and interest of the experts in this field is explored and comparisons have been made to establish the relative importance of determinants in achieving the objective. Judgments are expressed numerically as follows. A scale of 1-9 was used to compare two options [15] comparison values are as shown. 1-represents equal important 3-moderate important of one over another, 5-strong or essential important, 7- Very strong or demonstrated important, 9Extreme important. $2,4,6,8$ are intermediate values. A reciprocal pair-wise comparison is designated cautiously by fundamental scale. The judgment use reciprocals for transposed comparisons. Decisions are vocally given and the corresponding number is associated with that decision. A reciprocal was to designate row component. Matrix pair wise comparison is shown in Table.1 .Eigen vector of matrix is found out and its relative priority of criteria is measured. For the calculation of Eigen vectors, the elements are divided by the column sum and MATLAB was used for finding the Eigen values. For calculating the average of Eigen values, random consistency index $(\mathrm{CI})$ is calculated using the formula $\mathrm{CI}=(\lambda$ n) / (n-1) where $\lambda$ is the Eigen value and $n$ is order of its matrix. Random index RI is considered as 0.9 for a $4 * 4$ matrix and 0.58 for $3 * 3$ matrixes. Then $\mathrm{CR}=\mathrm{CI} / \mathrm{RI}<0.1$ [16]. The Eigenvector is used for the calculation of overall weighted effectiveness of ICT enabled process control system (OWEICTEPCS).

Table 1:-Pair-wise comparison of determinants

\begin{tabular}{|c|c|c|c|c|c|}
\hline & $\begin{array}{l}\text { Process } \\
\text { Optimizati } \\
\text { on } \\
(\mathrm{PO})\end{array}$ & $\begin{array}{l}\text { Intelligen } \\
\mathrm{t} \\
\text { Automati } \\
\text { on\& } \\
\text { Informati } \\
\text { on } \\
\text { Manage } \\
\text { ment } \\
\text { Systems( } \\
\text { IAIMS) }\end{array}$ & $\begin{array}{c}\text { Smart } \\
\text { Meterin } \\
\text { g } \\
\text { Technol } \\
\text { ogy(SM } \\
\text { T) }\end{array}$ & $\begin{array}{c}\text { Robust } \\
\text { and } \\
\text { Reliabl } \\
\text { e } \\
\text { Techno } \\
\text { logy } \\
\text { (RRT) }\end{array}$ & $\begin{array}{l}\text { Eigen } \\
\text { vector }\end{array}$ \\
\hline $\mathrm{PO}$ & 1 & 2 & 5 & 6 & 0.495 \\
\hline $\begin{array}{l}\text { IA } \\
\text { IM } \\
\text { S } \\
\end{array}$ & $1 / 2$ & 1 & 4 & 5 & 0.315 \\
\hline $\begin{array}{l}\text { SM } \\
T\end{array}$ & $1 / 5$ & $1 / 4$ & 1 & 4 & 0.132 \\
\hline $\begin{array}{l}\text { RR } \\
\mathrm{T} \\
\end{array}$ & $1 / 6$ & $1 / 5$ & $1 / 4$ & 1 & 0.059 \\
\hline
\end{tabular}

\subsubsection{Step 3:- Pair-wise comparison of} dimension:

The four dimensions pioneering method, information security, real time operation, and wireless control and its pair-wise comparison matrix was prepared. The relative ranking of each of it was calculated. Eigen vectors are found out as explained in the earlier session. Eigen vectors are labeledas Pja in Table 8. All determinants were assumed to be of equal relevance. Therefore same Eigen vectors were used as Pja for all the determinants. The values of the pair-wise comparison are shown in the Table2. 


\subsubsection{Step 4:- pair-wise comparison matrices between components/enablers level:}

The decision makers compare two components at a time with respect to an upper level criterion. Pair-wise comparisons of elements at each level are conducted with respect to relative influence towards the upper level criterion. For the Pair-wise comparison, the decision maker take the relative impact on 'wireless control' by an enabler ' $a$ ' when compared to enabler 'b', in improving Intelligent automation \&Information management system .The Pair-wise comparison matrix for wireless control under Intelligent automation \&Information management system is shown in Table 3 . The total number of pair-wise comparison matrices depends on the number of determinants and the dimension in the ANP network. Sixteen pair-wise comparison matrices are formed and Eigen vectors obtained are taken as ADkja in Table 8.

Table 2:- pair-wise comparison of dimensions with respect to pioneering method

\begin{tabular}{|l|l|l|l|l|l|}
\hline $\begin{array}{c}\text { Proces } \\
\text { s } \\
\text { Optim } \\
\text { ization } \\
\text { (PO) }\end{array}$ & $\begin{array}{l}\text { Pioneeri } \\
\text { ng } \\
\text { Method }\end{array}$ & $\begin{array}{l}\text { Informatio } \\
\text { n Security } \\
\text { (IS) }\end{array}$ & $\begin{array}{l}\text { Real } \\
\text { Time } \\
\text { Operat } \\
\text { ion } \\
\text { (RTO) }\end{array}$ & $\begin{array}{l}\text { Wirele } \\
\text { ss } \\
\text { Contro } \\
1\end{array}$ & $\begin{array}{l}\text { Eigen } \\
\text { vector }\end{array}$ \\
\hline PM & 1 & $1 / 2$ & 8 & 7 & 0.377 \\
\hline IS & 2 & 1 & 7 & 6 & \\
\hline RTO & $1 / 8$ & $1 / 7$ & 1 & $1 / 2$ & 0.492 \\
\hline WC & $1 / 7$ & $1 / 6$ & 2 & 1 & 0.079 \\
\hline
\end{tabular}

Table 3:- Pair-wise comparison matrix for wireless control under Intelligent automation \& Information management system Determinant

\begin{tabular}{|c|c|c|c|c|c|}
\hline $\begin{array}{l}\text { IAI } \\
\text { MS } \\
\text {,WC }\end{array}$ & $\begin{array}{l}\text { Greater } \\
\text { Flexibilit } \\
\text { y and } \\
\text { Mobility } \\
\text { for } \\
\text { Users. } \\
\text { (GFMU) }\end{array}$ & $\begin{array}{l}\text { Better } \\
\text { Efficie } \\
\text { ncy. } \\
\text { (BE) }\end{array}$ & $\begin{array}{l}\text { Cheap } \\
\text { Installation } \\
\& \\
\text { Maintenanc } \\
\text { e Cost. } \\
\text { (CIMC) }\end{array}$ & $\begin{array}{l}\text { User } \\
\text { Frien } \\
\text { dly. } \\
\text { (UF) }\end{array}$ & $\begin{array}{l}\text { Eigen } \\
\text { vector }\end{array}$ \\
\hline $\begin{array}{l}\text { GF } \\
\text { MU }\end{array}$ & 1 & 2 & 3 & 7 & 0.480 \\
\hline $\mathrm{BE}$ & $1 / 2$ & 1 & 3 & 5 & 0.314 \\
\hline $\begin{array}{l}\text { CIM } \\
\text { C }\end{array}$ & $1 / 3$ & $1 / 3$ & 1 & 3 & 0.147 \\
\hline UF & $1 / 7$ & $1 / 5$ & $1 / 3$ & 1 & 0.059 \\
\hline
\end{tabular}

\subsubsection{Step 5:- Pair-wise comparison matrices of interdependences}

Pair-wise comparisons are done to consider the interdependences among the enablers. The relative importance of greater flexibility and mobility for users when compared to better efficiency, cheap installation \& maintenance cost and user friendly with respect to wireless control and intelligent automation \&information management system is shown in Table 4. From Table 4, it is perceived that better efficiency has the maximum impact and user friendly has the minimum impact on wireless control and intelligent automation \&information management system. Fourteen such matrices are formed in this level. Similarly relative importance of all the enablers with respect to their corresponding dimensions and determinants are taken. Fifty six such matrices will be formed. The Eigen vectors from these matrices are displayed in first column of super matrices in Table 6 .

\subsubsection{Step 6:- Alternative evaluation:}

The final set of pair wise comparison was pursued for the relative impact of each of the alternatives (control within the process, centralized control within a particular area and control from geographically diverse locations) on the enablers to influence the determinants. The number of pair-wise comparison depends upon the number of enablers. Here 14 enablers for each determinants leading the formation of 56 such matrices. One such matrix is shown in Table 5. The Eigen vectors developed from this matrix are used in column Sikja of desirability indices matrix in Table 8 .

Table 4:- pair -wise comparison of matrix for enablers under intelligent automation $\&$ information management system, wireless control and greater flexibility and mobility for users

\begin{tabular}{|r|l|l|l|l|}
\hline $\begin{array}{l}\text { IAIM } \\
\text { S } \\
\text {,WC } \\
\text { GFM } \\
\text { U }\end{array}$ & $\begin{array}{l}\text { Better } \\
\text { Efficiency } \\
\text { (BE) }\end{array}$ & $\begin{array}{l}\text { Cheap } \\
\text { Installatio } \\
\text { n } \\
\text { \&Mainten } \\
\text { ance Cost. } \\
\text { (CIMC) }\end{array}$ & $\begin{array}{l}\text { User } \\
\text { Friendly. } \\
\text { (UF) }\end{array}$ & $\begin{array}{l}\text { Eigen } \\
\text { vector }\end{array}$ \\
\hline $\begin{array}{r}\text { BE } \\
\text { C }\end{array}$ & 1 & 2 & 9 & 0.587 \\
\hline UF & $1 / 2$ & 1 & 8 & 0.358 \\
\hline
\end{tabular}

Table 5:- Pair -wise comparison of matrix for alternatives impact on intelligent automation \& information management system, wireless control and greater flexibility and mobility for users

\begin{tabular}{|l|l|l|l|l|}
\hline $\begin{array}{l}\text { IAIMS } \\
\text {,WC } \\
\text { GFMU }\end{array}$ & $\begin{array}{l}\text { Control } \\
\text { Within } \\
\text { the } \\
\text { Process } \\
\text { (CWP) }\end{array}$ & $\begin{array}{l}\text { Centralized } \\
\text { Control } \\
\text { Within a } \\
\text { Particular } \\
\text { Area } \\
\text { (CCWP) }\end{array}$ & $\begin{array}{l}\text { Control } \\
\text { from } \\
\text { Geograp } \\
\text { hically } \\
\text { Diverse } \\
\text { locations } \\
\text { (CGD) }\end{array}$ & $\begin{array}{l}\text { Eigen } \\
\text { vector }\end{array}$ \\
\hline CWP & 1 & 6 & 7 & 0.739 \\
\hline CCWP & $1 / 6$ & 1 & 3 & 0.179 \\
\hline CGD & $1 / 7$ & $1 / 3$ & 1 & 0.082 \\
\hline
\end{tabular}

\subsubsection{Step 7:- Formulation of Super matrixes:}

A partitioned matrix is a super matrix where each sub matrix depends on the levels represented by the model. The super matrix allows the resolution of the interdependences that exist among the elements of the system. The local priority vectors are entered in the appropriate column of the super matrix. Here four determinants hence four super matrices. Super matrix ' $M$ ' for intelligent automation \& information management system is shown in Table 6. The non-zero values in the column of super matrix are the important weights associated with the interdependence pair-wise comparison of matrices. In the next stage, to obtain long term stable sets of weights the super matrix $\mathrm{M}$ is made to converge. The power of super matrix $\mathrm{M}$ is raised to $\mathrm{M} \mathrm{k+1}$ where $\mathrm{k}$ is a large arbitrary number. Raising the power of super matrix allows for the convergence of the interdependent relationships [17]. In this study, convergence is 
reached at M108. There is no trivial difference between M108 andM109 .That means convergence is obtained at M108 and is shown in Table7.
This was done by using MATLAB. Similarly the other three matrices were formed.

Table 6:- Super matrix $M$ for intelligent automation \&information management system before convergence

\begin{tabular}{|c|c|c|c|c|c|c|c|c|c|c|c|c|c|c|}
\hline & IFS & EOP & MOR & HII & II & IC & IP & ICA & $\begin{array}{l}\text { MO } \\
\mathrm{D}\end{array}$ & SDPV & $\begin{array}{l}\text { GF } \\
\text { MU }\end{array}$ & $\mathrm{BE}$ & $\begin{array}{l}\text { CIM } \\
\mathrm{C} \\
\end{array}$ & UF \\
\hline IFS & 0 & 0.490 & 0.735 & 0.748 & & & & & & & & & & \\
\hline EOP & 0.525 & 0 & 0.065 & 0.071 & & & & & & & & & & \\
\hline MOR & 0.334 & 0.312 & 0 & 0.180 & & & & & & & & & & \\
\hline HII & 0.142 & 0.198 & 0.199 & 0 & & & & & & & & & & \\
\hline II & & & & & 0 & 0.90 & $\begin{array}{r}0.8 \\
89 \\
\end{array}$ & & & & & & & \\
\hline IC & & & & & 0.90 & 0 & $\begin{array}{r}0.1 \\
11\end{array}$ & & & & & & & \\
\hline IP & & & & & 0.10 & 0.10 & 0 & & & & & & & \\
\hline ICA & & & & & & & & 0 & 0.90 & 0.889 & & & & \\
\hline $\begin{array}{l}\text { MO } \\
\text { D }\end{array}$ & & & & & & & & 0.90 & 0 & 0.111 & & & & \\
\hline $\begin{array}{l}\text { SDP } \\
\mathrm{V}\end{array}$ & & & & & & & & 0.10 & 0.10 & 0 & & & & \\
\hline $\begin{array}{l}\text { GFM } \\
\mathrm{U}\end{array}$ & & & & & & & & & & & 0 & $\begin{array}{r}0.5 \\
87\end{array}$ & 0.786 & 0.647 \\
\hline $\mathrm{BE}$ & & & & & & & & & & & $\begin{array}{r}0.58 \\
7 \\
\end{array}$ & 0 & 0.068 & 0.098 \\
\hline $\begin{array}{l}\text { CIM } \\
\mathrm{C} \\
\end{array}$ & & & & & & & & & & & $\begin{array}{r}0.35 \\
8\end{array}$ & $\begin{array}{r}0.3 \\
58\end{array}$ & 0 & 0.254 \\
\hline UF & & & & & & & & & & & $\begin{array}{c}0.05 \\
5\end{array}$ & $\begin{array}{l}0.0 \\
55\end{array}$ & 0.146 & 0 \\
\hline
\end{tabular}

TABLE 7:- Super matrix $M$ for intelligent automation \& information management system after convergence

\begin{tabular}{|c|c|c|c|c|c|c|c|c|c|c|c|c|c|c|}
\hline & IFS & EOP & MOR & HII & II & IC & IP & ICA & $\begin{array}{l}\mathrm{MO} \\
\mathrm{D}\end{array}$ & $\begin{array}{l}\text { SDP } \\
\text { V }\end{array}$ & $\begin{array}{l}\text { GF } \\
\text { MU }\end{array}$ & $\mathrm{BE}$ & $\begin{array}{l}\text { CIM } \\
\text { C }\end{array}$ & UF \\
\hline IFS & $\begin{array}{l}0.39 \\
3 \\
\end{array}$ & 0.393 & 0.392 & 0.392 & & & & & & & & & & \\
\hline EOP & $\begin{array}{r}0.23 \\
2\end{array}$ & 0.232 & 0.231 & 0.231 & & & & & & & & & & \\
\hline MOR & $\begin{array}{r}0.23 \\
0\end{array}$ & 0.230 & 0.230 & 0.230 & & & & & & & & & & \\
\hline HII & $\begin{array}{r}0.14 \\
7 \\
\end{array}$ & 0.147 & 0.147 & 0.147 & & & & & & & & & & \\
\hline II & & & & & 0.473 & 0.473 & 0.473 & & & & & & & \\
\hline IC & & & & & 0.436 & 0.436 & 0.436 & & & & & & & \\
\hline IP & & & & & 0.091 & 0.091 & 0.091 & & & & & & & \\
\hline ICA & & & & & & & & $\begin{array}{l}0.47 \\
3\end{array}$ & 0.473 & 0.473 & & & & \\
\hline $\begin{array}{l}\text { MO } \\
\mathrm{D}\end{array}$ & & & & & & & & $\begin{array}{l}0.43 \\
6 \\
\end{array}$ & 0.436 & 0.436 & & & & \\
\hline $\begin{array}{l}\text { SDP } \\
\text { V }\end{array}$ & & & & & & & & $\begin{array}{l}0.09 \\
1\end{array}$ & 0.091 & 0.091 & & & & \\
\hline $\begin{array}{l}\text { GFM } \\
\text { U }\end{array}$ & & & & & & & & & & & $\begin{array}{l}0.40 \\
2\end{array}$ & 0.402 & 0.402 & $\begin{array}{l}0.4 \\
02\end{array}$ \\
\hline $\mathrm{BE}$ & & & & & & & & & & & $\begin{array}{r}0.26 \\
1 \\
\end{array}$ & 0.261 & 0.261 & $\begin{array}{r}0.2 \\
61 \\
\end{array}$ \\
\hline $\begin{array}{l}\text { CIM } \\
\text { C } \\
\end{array}$ & & & & & & & & & & & $\begin{array}{r}0.25 \\
6\end{array}$ & 0.256 & 0.256 & $\begin{array}{r}0.2 \\
56\end{array}$ \\
\hline UF & & & & & & & & & & & $\begin{array}{r}0.07 \\
4\end{array}$ & 0.074 & 0.074 & $\begin{array}{r}0.0 \\
74\end{array}$ \\
\hline
\end{tabular}

\subsubsection{Step 8:- Best Alternative Selection}

For an alternative $\mathrm{i}$ and determinant a , the desirability index is defined as,

Dia $=\Sigma \Sigma$ PjaADKjaAIkjaSiKja
$\mathrm{J}=1 \mathrm{k}=1$

Here Pja is the relative importance weight of dimension $\mathrm{j}$ on the determinant ' $a$ ', ADkja-the relative importance weight for enabler $\mathrm{k}$, dimension $\mathrm{j}$ and determinant ' $\mathrm{a}$ ' for the dependence 
(D) relationship between enablers levels, AIkja is the stabilized relative importance weight for attribute enabler $\mathrm{K}$ of ' $\mathrm{j}$ 'dimension in the determinant ' $a$ ' for interdependence (I), relationships within the attribute enablers component level. Sikja-the relative impact of ICT enabled control system alternative model ' $i$ 'on ICT enabled control system ' $k$ ' of dimension 'j' of ICT enabled control system hierarchy network. The calculation for desirability indices for alternatives based on the intelligent automation \& information management system determinant is shown in Table 8. The results from the pair wise comparison of determinants are incorporated in the second column of the table,

Table 8:- Total desirability indices for intelligent automation $\&$ information management system

\begin{tabular}{|c|c|c|c|c|c|c|c|c|c|c|c|}
\hline $\begin{array}{l}\text { Dimens } \\
\text { ions }\end{array}$ & $\mathrm{Pja}$ & Enablers & ADkja & AIaJa & Product & S1kja & S2kja & S3kja & CWP & CCPA & CGDL \\
\hline $\mathrm{PM}$ & 0.367 & IFS & 0.367 & 0.393 & 0.053 & 0.681 & 0.118 & 0.201 & 0.036 & 0.118 & 0.011 \\
\hline PM & 0.367 & EOP & 0.498 & 0.232 & 0.042 & 0.750 & 0.162 & 0.087 & 0.032 & 0.007 & 0.004 \\
\hline $\mathrm{PM}$ & 0.367 & MOR & 0.052 & 0.230 & 0.004 & 0.777 & 0.155 & 0.069 & 0.003 & 0.001 & 0.000 \\
\hline $\mathrm{PM}$ & 0.367 & HII & 0.082 & 0.147 & 0.004 & 0.790 & 0.133 & 0.077 & 0.003 & 0.001 & 0.000 \\
\hline IS & 0.498 & II & 0.785 & 0.473 & 0.185 & 0.751 & 0.150 & 0.099 & 0.139 & 0.028 & 0.018 \\
\hline IS & 0.498 & IC & 0.128 & 0.436 & 0.028 & 0.685 & 0.093 & 0.221 & 0.019 & 0.003 & 0.006 \\
\hline IS & 0.498 & IP & 0.087 & 0.091 & 0.004 & 0.700 & 0.107 & 0.194 & 0.003 & 0.000 & 0.001 \\
\hline $\mathrm{RO}$ & 0.052 & ICA & 0.798 & 0.473 & 0.020 & 0.767 & 0.085 & 0.148 & 0.015 & 0.002 & 0.003 \\
\hline RO & 0.052 & MOD & 0.122 & 0.436 & 0.003 & 0.753 & 0.075 & 0.172 & 0.002 & 0.000 & 0.000 \\
\hline $\mathrm{RO}$ & 0.052 & SDPV & 0.080 & 0.091 & 0.000 & 0.700 & 0.107 & 0.194 & 0.000 & 0.000 & 0.000 \\
\hline WC & 0.082 & GFMU & 0.480 & 0.402 & 0.016 & 0.739 & 0.179 & 0.082 & 0.012 & 0.003 & 0.001 \\
\hline WC & 0.082 & $\mathrm{BE}$ & 0.314 & 0.261 & 0.007 & 0.755 & 0.154 & 0.092 & 0.005 & 0.001 & 0.001 \\
\hline WC & 0.082 & CIMC & 0.147 & 0.256 & 0.003 & 0.164 & 0.297 & 0.539 & 0.001 & 0.001 & 0.002 \\
\hline$\overline{\mathrm{WC}}$ & 0.082 & UF & 0.059 & 0.074 & 0.000 & 0.685 & 0.221 & 0.093 & 0.000 & 0.000 & 0.000 \\
\hline & & & & & & \multicolumn{3}{|c|}{ Total desirability indices } & 0.270 & 0.164 & 0.047 \\
\hline
\end{tabular}

the resulting weight obtained from the converged super matrix is displayed in the fifth column of the table .In the sixth column, the product of second, fourth and fifth columns are ((Pja*ADkja*Alkja) displayed and weights obtained from the pair wise comparisons of the alternatives are displayed in the seventh, eighth and ninth columns of the table. The desirability index (Pja*ADkja*AIkja*Sikja) of each alternative is shown in the final three columns of the table. Then total desirability indices for each alternative are calculated by using the equation (1). Similarly total desirability indices analysis is carried out for other three determinants.

\subsubsection{Step 9:- Calculation of overall weighted Effectiveness ICT enabled process control system (OWEICTEPCS)}

The overall weighted effectiveness of ICT enabled process control system for an alternative ' $\mathrm{i}$ ' (OWEICTEPCSi) is the summation of the product of the desirability indices (Dia) and the relative important weight of the determinant $(\mathrm{Ca})$ of the ICT enabled process control system and it can be represented by the equation,

OWEICTEPCSi $=\Sigma$ DiaCa.

Values of OWEICTEPCS and normalized value for OWEICTEPCS (NOWEICTEPCS) is shown in table 9.In this table first row comprises the weights, which can be obtained from the Eigen vectors of pair-wise comparison of determinants (step 2). The remaining elements of the first, second, third and fourth columns are the total desirability indices obtained under process optimization, intelligent automation \& information management systems, smart metering technology and robust and reliable technology. Then OWEICTEPCS can be calculated by using the equation (2).

For example the calculation of OWEICTEPCS for control within the process is shown below.
OWEICTEPCSCWP $=(0.495 * 0.246)+(0.315 * 0.270)+(0.132 *$ $0.227)+(0.059 * 0.288)=0.254$.

NOWEICTEPCS can be obtained by dividing each element in the sixth column of the table by the sum of all the elements in the same column; and its normalized value is 0.626 which shows that control within the process is the most suitable alternative for ICT enabled process control system following control from geographically diverse locations and Centralized Control within a Particular Area.

Table 9:- Values of OWEICTEPCS\&NOWEICTEPCS

\begin{tabular}{|l|c|l|c|c|c|c|}
\hline $\begin{array}{l}\text { Alter } \\
\text { nativ } \\
\text { es }\end{array}$ & $\begin{array}{c}\text { Proce } \\
\text { ss } \\
\text { Opti } \\
\text { mizat } \\
\text { ion }\end{array}$ & $\begin{array}{l}\text { Intelligent } \\
\text { Automatio } \\
\text { \&Informat } \\
\text { ion } \\
\text { Managem } \\
\text { ent } \\
\text { systems }\end{array}$ & $\begin{array}{c}\text { Smart } \\
\text { Meteri } \\
\text { ng } \\
\text { Techn } \\
\text { ology }\end{array}$ & $\begin{array}{c}\text { Robu } \\
\text { st } \\
\text { and } \\
\text { Relia } \\
\text { ble } \\
\text { Tech } \\
\text { nolog } \\
\text { y }\end{array}$ & $\begin{array}{l}\text { OWS } \\
\text { I }\end{array}$ & $\begin{array}{l}\text { NO } \\
\text { WS } \\
\text { I }\end{array}$ \\
\hline $\begin{array}{l}\text { Weig } \\
\text { hts }\end{array}$ & 0.495 & 0.315 & 0.132 & 0.059 & & \\
\hline $\begin{array}{l}\text { CWP } \\
0.246\end{array}$ & 0.270 & 0.227 & 0.288 & 0.254 & $\begin{array}{c}0.62 \\
6\end{array}$ \\
\hline $\begin{array}{l}\text { CCP } \\
\text { A }\end{array}$ & 0.059 & 0.164 & 0.052 & 0.037 & 0.090 & $\begin{array}{c}0.22 \\
2\end{array}$ \\
\hline $\begin{array}{l}\text { CGD } \\
\text { L }\end{array}$ & 0.077 & 0.047 & 0.045 & 0.047 & 0.062 & $\begin{array}{c}0.15 \\
2\end{array}$ \\
\hline
\end{tabular}

\section{RESULTS AND DISCUSSION}

ICT enabled control system is making a drastic change in the industrial field. Due to this reason the industrialists and academicians are giving more importance to reduce the issues 
related to the implementation of ICT enabled control system in process industries. In this paper an analysis is made for the successful implementation of the best ICT enabled control system in the industry with the aid of ANP model in a fertilizers and chemicals industry in central Kerala. It measures the relative strength and impact between elements in the network model. This decision model incorporates and relies upon the distinctiveness of ICT enabled control system. After a thorough discussion with a group of experts in $\mathrm{ABC}$, the determinant, dimensions, and enablers are found out. It is a tiresome and prolonged chore for the formulation of pair-wise comparison matrices and the remaining processes to complete the work. Around 138 matrices are formed for completing the study. Calculation of overall weighted effectiveness ICT enabled process control system and its normalized value helped to obtain the result.

\section{CONCLUSIONS}

In the present work the expert group of $\mathrm{ABC}$ utilized $\mathrm{ANP}$, a well-known decision making tool, for selecting the best ICT enabled process control system for the industry. Findings of the study state that 'control within the process' is the best ICT enabled control system among the three, following 'control from geographically diverse locations' and 'centralized control within a particular area'. Even though these results do not assert the enduring dominance of one alternative over the other, the industrialists of $\mathrm{ABC}$ agreed that after having some more study about the proposed model, they would try to implement the model - initially for small loops. After the successful implementation of the small control loops, the implementation of the model can be extended to large loops with the help of modern security systems

\section{REFERENCES}

[1] Mani.; A \& C,A Patvardhan 2006; Study of ICT Enabled Laboratories, Bottom of Form India Conference, Annual IEEE, pp 1-6, 15-17, September 15-17 .

[2] Saaty, T.L, 2006 ;'Rank from comparisons and from ratings in the analytic hierarchy/network processes'. European Journal of Operational Research, Vol168,issue 2,PP:557-570.

[3] Chen. S.H. , H.T. Lin. and H.T Lee, 2008; Applying ANP approach to partner selection for strategic alliance, Management Decision, Vol 46 ,issue 3,pp:449-465.

[4] SaatyT.L, 1999, Fundamentals of the analytic network process, ISAHP 1999, Kobe, Japan, PP: August 12-14.

[5] Bottero M, G Modini, 2008; An appraisal of analytic network process and its role in sustainability assessment in Northern Italy. Management of Environmental Quality: An International Journal; Vol19, issue 6, 642-660.
[6] Ambika Devi Amma . T, V.R Pramod. And N Radhika, 2013. MCDM Approach for the Adoption of Best Cloud, International Journal of Computer Applications. Vol 63; issue 15,pp:20-26.

[7] Rafael Diaz and Barry Charles Ezell; 2012; Using Analytical Network Process Decision Methodology to Analyze and Allocate Resources in the U.S. Army Training Support System. International Journal of Operations Research and Information Systems, Vol 3,issue 3, pp: 53-73.

[8] Shu-Fang Lee\&Wen-Shiung Lee, 2011; Using MCDM to promote the quality of the hospital service for children with developmental delays. The Service Industries Journal; Published online: pp 1-13.

[9] Godse. M, R Sonar; Mulik, S, 2008 ; Web ,Service Selection Based on Analytical Network Process Approach. AsiaPacific Services Computing Conference, APSCC '08. IEEE, pp 1103-1108, 9-12 .

[10] James A. W. Mulebeke, Li Zheng, 2006; Analytical network process for software selection in product development: A case study, Journal of engineering and technology management, Vol 23, issue 4, pp 337-352.

[11] Bottero. M, V.Ferretti, 2010; An analytic network processbased approach for location problems: the case of a new waste incinerator plant in the Province of Torino (Italy), Journal of Multi-Criteria Decision Analysis, Volume 17, Issue 3-4, pages 63-84.

[12] Xiang He, AYener,; 2013,End-to-End Secure Multi-Hop Communication with Un trusted Relays, IEEE Transactions on Wireless communications, Volume:12 Issue:1 ,pp:1-11,

[13] http://searchsecurity.techtarget.com/definition/applicationblacklisting, August 2013

[14] http://freewimaxinfo.com/point-to-point wireless networks.html, August 2013

[15] Saaty T.L, 1996,Decision-making with feedback: The Analytic network process, RWS publications. Pittsburg,PA,),

[16] Saaty T.L, 2003,Decision-making with the AHP: Why is the principal eigenvector necessary, European Journal of Operational Research, Vol 145, issue 1, 85-91, February

[17] Meade. L \& J, Sarkis, 1999, Analysing organizational project alternatives for agile manufacturing process: an analytical network approach, International Journal of Production Research, Vol 37,issue 2, pp 241-261,. 